\title{
Increased Chromosomal Aberrations in Peripheral Blood Lymphocytes of Traffic Policemen of Amritsar City
}

\author{
Shalinder Singh Kamboj and Vasudha Sambyal \\ Department of Human Genetics, Guru Nanak Dev University, Amritsar 143 005, Punjab, India
}

KEYWORDS Lymphocytes; chromosomal aberrations; acrocentric associations; traffic policemen; Amritsar

\begin{abstract}
Chromosomal aberrations were investigated in cultured Lymphocytes of 21 traffic policemen occupationally exposed to automobile exhaust and 13 residents of Amritsar city not occupationally exposed to automobile exhaust to assess the genotoxic effects of increasing air pollution of Amritsar city, Punjab (India). The mean percentage frequency of total aberrant metaphases $(31.12 \pm 10.12)$, metaphases with numerical aberrations (4.39 \pm 2.62$)$, structural aberrations including gaps $(2.38 \pm 1.91)$, structural aberrations excluding gaps (2.24 \pm 1.68$)$ and

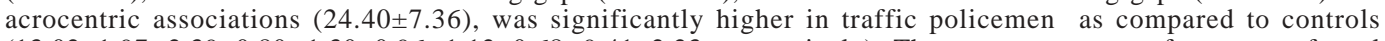
$(13.02 \pm 1.97,2.39 \pm 0.80,1.30 \pm 0.96,1.12 \pm 0.68,9.41 \pm 2.23$, respectively). The mean percentage frequency of total aberrant metaphases (40.03 \pm 7.84$)$, metaphases with numerical aberrations $(5.65 \pm 2.58)$, structural aberrations including gaps (3.62 \pm 1.71$)$, structural aberrations excluding gaps (3.34 \pm 1.34$)$, and acrocentric associations(30.76 \pm 6.09$)$ was also significantly higher in traffic policemen working more than 10 years as compared to traffic policemen working less than 10 years $(24.52 \pm 5.72,3.44 \pm 2.49,1.45 \pm 1.47,1.42 \pm 1.27$ and $19.63 \pm 3.72$, respectively). The result indicates increased chromosomal aberrations and acrocentric associations due to occupational exposure to polluted air having increased concentration of automobile exhausts, and these effects increased with increasing duration of exposure.
\end{abstract}

\section{INTRODUCTION}

Air pollution in India has been aggravated by a number of developments, such as, growth in the size of cities, rapid economic development, industrialization, and increasing traffic and levels of energy consumption. Many urban air pollutants are recognized to be mutagenic and carcinogenic agents. Amritsar city in the state of Punjab (North India) has an area of $120.55 \mathrm{sq} . \mathrm{km}$ and the population is $1,229,561$ with a high population density of 10,200 persons per sq.km (State Information 2003; STP 2004). The suspended particulate matter (SPM) levels of ambient air of the city as reported since 1997 is $400 \mu \mathrm{g} / \mathrm{m}^{3}$ which is almost three times the National Ambient Air Quality Standards for India (NAAQSI) $\left(140 \mu \mathrm{g} / \mathrm{m}^{3}\right)$. Though there are no guideline values for long-term average SPM concentrations recommended by World Health Organization, studies have shown that the prevalence of bronchitis symptoms in children, and of reduced lung function in children and adults are associated with particulate matter exposure at annual average concentration levels

Address for Correspondence: Dr. Vasudha Sambyal, Sr. Lecturer, Department of Human Genetics, Guru Nanak Dev University, Amritsar 143 005, Punjab, India Telephone: +91-183-2258802-09 Ext. 3445

E-mail:vasudhasambyal@yahoo.co.in even below $20 \mu \mathrm{g} / \mathrm{m}^{3}$ (as PM 2.5) or $30 \mu \mathrm{g} / \mathrm{m}^{3}$ (as PM 10) (WHO 2003b). . The current level of lead in Amritsar air is not known, though $\mathrm{SO}_{2}$ and $\mathrm{NO}_{2}$ are lower than the WHO limit (Table 1). In Amritsar, the major sources of air pollution are automobiles, and numerous small-scale industries, such as, textile processing, pharmaceutical, iron foundries, steel plants, glass and plastic mills, pulp and paper mills, dairy, woollen dyeing and electroplating.

The purpose of the present study was to investigate with cytogenetic method the effects of consistent exposure to polluted air containing automobile exhausts on traffic policemen of Amritsar city.

\section{MATERIALS AND METHODS}

The study includes 21 traffic policemen and 13 male controls of similar age. All the study participants were residents of Amritsar city exposed to similar level of ambient air pollution. The traffic policemen were consistently exposed to increased automobile exhausts at the busy road intersections of Amritsar city during their 8 $\mathrm{h}$ duty per day, 6 days a week. The control group consisted of residents (8 security personnel and 5 students) of Guru Nanak Dev University Campus situated at a distance of $7 \mathrm{~km}$ from the city centre, spread over an area having less traffic 
and adequate green cover with large number of open spaces. All participants were informed of the study aims and asked to complete a selfadministrated standardized questionnaire form under informed consent. Personal history, such as past and present illness and medication, information about the total conceptions, number of live children, miscarriages, spontaneous abortions, postnatal death, birth defects and health of children, family income, family size, habitat and surroundings, diet pattern, such as frequency of consumption of non-vegetarian food, pulses, vegetables and fruits, was obtained from each participant.

Traffic policemen included in the study had worked for at least 8 months to 21 years with the mean duration of road duties being $8.36 \pm 6.73$ years. Traffic policemen and controls were in the age range of 28 to 45 years (mean $34.66 \pm 4.06$ ) and 23 to 51 years (mean 33.20 \pm 7.91 ), respectively, at the time of study. All study participants were non-smokers. $61.90 \%$ of traffic policemen and $38.46 \%$ of controls were consuming alcohol, with the quantity and frequency of consumption being 100 to $150 \mathrm{ml}$, once or twice a week. The staple diet of all participants was vegetarian, but $71.43 \%$ of traffic policemen and $38.46 \%$ of controls were taking non-vegetarian food, eggs and meat, once or twice a week. All traffic policemen and controls were having similar diet pattern and socio-economic status.

Chromosomal Aberration Analysis: Peripheral blood culture was set up by standard protocol (Moorhead et al. 1960). $5 \mathrm{ml}$ of peripheral blood sample per subject was taken in heparinized syringes. Lymphocyte cultures were set up by adding approximately $2 \mathrm{ml}$ of autologous supernatant plasma along with lymphocytes from buffy coat to $8 \mathrm{ml}$ of RPMI1640 (HiMedia), supplemented with $0.125 \%$ gentamycine sulphate (Glenmark) as antibiotic and $0.2 \mathrm{ml}$ of PHA-M (Gibco) as mitogen. The cultures were incubated at $37^{\circ} \mathrm{C}$ for $71 \mathrm{~h}$ and exposed to $0.05 \mathrm{ml}$ of colcemid (Sigma) at $10 \mathrm{mg} /$ $\mathrm{ml}$ final concentration for the last $1 \mathrm{~h}$ before harvesting. The cells were harvested by the standard procedure using $0.075 \mathrm{M} \mathrm{KCl}$ as a hypotonic solution and methanol:acetic acid (3:1) as fixative. The slides were stained with Giemsa, coded and scored blind.

Scoring and Statistical Analysis: 100 well spread second division metaphases were scored for chromosomal analysis. The number of Total aberrant metaphases(TAM), metaphases with numerical aberrations, metaphases with structural aberrations (including and excluding gaps) and metaphases with acrocentric associations were scored. The latter were further scored as metaphases with single and metaphases with multiple acrocentric associations. The number of chromosomes involved in the association was also scored. Statistical analysis of the data was performed using Student's t-test.

\section{RESULTS}

The results have shown an increased frequency and variety of chromosomal aberrations in traffic policemen as compared to controls. Numerical aberrations found were polyploidy, double minutes, acentric fragments, hyper and hypoploid metaphases. Structural aberrations found were chromatid breaks and gaps, chromatid deletions, additions, radial chromosomes, diplochromosomes, pulverizations, endoreduplications, centromeric separations, dicentrics and ring chromosomes. Apart from numerical and structural aberrations, there was an unusually high incidence of acrocentric associations in the scanned metaphases. The number of chromosomes involved in an acrocentric association was higher and the number of

Table 1: Status of ambient air quality of Amritsar (NAAQSI 2003, WHO 2003a,b; PPCB 2004)

\begin{tabular}{|c|c|c|c|}
\hline Year & $\begin{array}{c}S P M\left(\mu \mathrm{g} / \mathrm{m}^{3}\right) \\
\text { WHO limit - no guideline } \\
\text { NAQQS - } 140 \mu \mathrm{g} / \mathrm{m}^{3}\end{array}$ & $\begin{array}{c}\mathrm{SO}_{2}\left(\mu \mathrm{g} / \mathrm{m}^{3}\right) \\
W H O \text { limit }-50 \mu \mathrm{g} / \mathrm{m}^{3} \\
N A Q Q S-60 \mu \mathrm{g} / \mathrm{m}^{3}\end{array}$ & $\begin{array}{c}N O_{x}\left(\mu g / m^{3}\right) \\
W H O \text { limit }-40 \mu g / m^{3} \\
N A Q Q S-60 \mu g / m^{3}\end{array}$ \\
\hline 1997 & 140 & 17 & 44 \\
\hline 1998 & 447 & 16 & 42 \\
\hline 1999 & 439 & 20 & 43 \\
\hline 2000 & 408 & 11 & 17 \\
\hline 2001 & 396 & 17 & 20 \\
\hline 2002 & 416 & 15 & 26 \\
\hline 2003 & 433 & 13 & 30 \\
\hline
\end{tabular}


acrocentric associations in a metaphase was significantly higher in traffic policemen as compared to controls. In controls, majority $(84.33 \%)$ of acrocentric associations were involving two acrocentric chromosomes (D and G, D and D, and G and G group), and only $15.67 \%$ metaphases involved three acrocentrics (3D, 2D and $\mathrm{G}$, and $2 \mathrm{G}$ and $\mathrm{D}$ ). In traffic policemen, two chromosome associations were $75.94 \%$, three chromosome associations were $21.88 \%$, four chromosome (2D and 2G, 3G and D, 3D and G, and $4 \mathrm{D}$ and $4 \mathrm{G}$ ) associations were $6.17 \%$, and $0.58 \%$ was five chromosome ( $3 \mathrm{D}$ and $2 \mathrm{G}$ ) associations.

The mean percentage frequency of total aberrant metaphases, metaphases with numerical and structural aberrations (including and excluding gaps) and metaphases with acrocentric associations (multiple and single) were significantly higher in traffic policemen as compared to controls (Table 2) as well as in traffic policemen working more than 10 years as compared to those working less than 10 years (Table 3).

The percentage frequency of TAM was higher but statistically non-significant in traffic policemen $\geq 35$ years in age as compared to subjects $<35$ years in age. The controls $\geq 35$ years in age had slightly lower number of aberrations as compared to subjects $<35$ years in age. The percentage frequency of TAM was significantly higher in controls taking alcohol but was non-significantly higher in traffic policemen as compared to those not taking alcohol (Table 4).

All traffic policemen and controls were apparently healthy, but seven $(33.33 \%)$ traffic policemen reported coughing and breathlessness. All traffic policemen and married controls were having healthy children except one traffic policeman who was infertile. Among traffic policemen, one case of spontaneous abortion, one case of miscarriage and one case of postnatal death were reported, and one control reported miscarriage twice. Any relation of these observations to the pollution could not be ascertained.

\section{DISCUSSION}

The results of the study have shown significantly higher frequencies of chromosomal aberrations and unusually high acrocentric associations in traffic policemen than the controls (Table 2). Acrocentric associations were considered as harbinger of aberrations, as they could result into Robertsonian translocation and aneuploidy in future cell divisions. Previous studies on traffic policemen have not reported frequency of acrocentric associations. Traffic policemen are occupationally exposed to increased automobile exhausts .Higher occupational exposure to automobile exhausts and SPM at the city intersections can be the cause of elevated chromosomal aberrations and Acrocentric associations in traffic policemen compared to the controls. In Amritsar there are a large number of two and three- wheelers and cars and the total number of registered vehicles from the year 1950 to April 2004 is 469,953 with the number of vehicles per thousand persons being 153 (DTO 2004). There are no strict pollution norms for vehicles and very old and even poorly maintained vehicles are still operating leading to high vehicular emissions. Adulterated petrol is in use, and majority of the three-wheelers use mixture of diesel and kerosene as fuel which causes a lot of pollution (Vehicular Pollution 2003). Most of the roads cater to manually driven

Table 2: Chromosomal aberrations found in controls and traffic policemen

\begin{tabular}{lrrr}
\hline Type of aberrations & $\begin{array}{c}\text { Mean } \pm S D \\
\text { in controls }\end{array}$ & $\begin{array}{c}\text { Mean } \pm \text { SD } \\
\text { in traffic policemen }\end{array}$ & $\begin{array}{c}\text { Student's t-test } \\
\text { distribution }\end{array}$ \\
\hline \% frequency of TAM & $13.02 \pm 1.97$ & $31.12 \pm 10.12$ & $(\mathrm{p}<0.005), \mathrm{sig}^{\mathrm{f}}$ \\
\% frequency of metaphases with NA & $2.39 \pm 0.80$ & $4.39 \pm 2.62$ & $(\mathrm{p}<0.005), \mathrm{sig}^{\mathrm{f}}$ \\
$\%$ frequency of metaphases with SA including gaps & $1.30 \pm 0.96$ & $2.38 \pm 1.91$ & $(\mathrm{p}<0.05), \quad \mathrm{sig}^{\mathrm{f}}$ \\
$\%$ frequency of metaphases with SA excluding gaps & $1.12 \pm 0.68$ & $2.24 \pm 1.68$ & $(\mathrm{p}<0.05), \mathrm{sig}^{\mathrm{f}}$ \\
$\%$ frequency of metaphases with AA & $9.41 \pm 2.23$ & $24.40 \pm 7.36$ & $(\mathrm{p}<0.005), \mathrm{sig}^{\mathrm{f}}$ \\
$\%$ frequency of metaphases with multiple AA & $1.79 \pm 0.70$ & $7.92 \pm 3.84$ & $(\mathrm{p}<0.005), \mathrm{sig}^{\mathrm{f}}$ \\
$\%$ frequency of metaphases with single AA & $7.62 \pm 1.55$ & $16.48 \pm 4.61$ & $(\mathrm{p}<0.005), \mathrm{sig}^{\mathrm{f}}$ \\
\hline
\end{tabular}

TAM = Total aberrant metaphases; $\quad \mathrm{NA}=$ Numerical aberrations;

$\mathrm{SA}=$ Structural aberrations; $\quad \mathrm{AA}=$ Acrocentric associations;

$\operatorname{sig}^{\mathrm{f}}=$ Statistically significant difference. 
carts, slow-moving rickshaws, speeding two and four-wheelers and heavily loaded buses and trucks and are over-congested. There is also infrequent cleaning of dust from the sides of roads which results in increased SPM as the traffic moves. Thus, the vehicles are not driven at optimum speed giving low fuel efficiency and high level of emissions. Automobiles are major sources of SPM and the dust present on the sides of the roads also leads to increased SPM as the traffic moves. Thus the traffic policemen are also more exposed to SPM. Seven $(33.33 \%)$ traffic policemen reported coughing and breathlessness. The possible explanation can be their higher exposure to SPM. Impaired immune response has been reported (WHO 2003a) in rats exposed to resuspended road dust at $360 \mathrm{mg} / \mathrm{m}^{3}$ relative to exposure to either clean air or ammonium nitrate exposure, leading to lowered resistance to respiratory infection, at an exposure duration of $4 \mathrm{~h} /$ day for 4 days/week for 8 weeks There are studies reporting increased chromosomal aberrations in individuals occupationally exposed to petrol and diesel exhausts and fumes (Hogstedt et al. 1981; Sobti and Bhardwaj 1993; Carere et al. 1995; Khalil 1995; Knudsen et al. 1999; Chitra et al. 2001; Burgaz et al. 2002). The urban airborne particles have also been shown to have genotoxic activity (Clonfero 1997; Zhao et al. 2002).

Emissions from automotive sources are estimated nowadays to be the main cause of mutagenic/ carcinogenic risk for people living in urban areas of industrialized countries. Soot emitted by motor vehicles contains variable quantities of adsorbed highly genotoxic compounds, polycyclic aromatic hydrocarbons (PAHs) and their nitro derivatives, i.e., nitroarenes. The latter are among the compounds with the highest genotoxic activity according to Ames test (genetic point mutation on bacteria) and are particularly abundant in ultra fine particulate matter ( $<1.1$ microns) emitted by diesel engines. Diesel emissions have been considered as probable carcinogenic agents for man by the International Agency for Research on Cancer (IARC) (Clonfero and Saia 1991; Clonfero 1997). Thus, the individuals occupationally exposed to pollutants in automobile exhausts are at increased health risk. As the automobiles are the main sources of PAHs, traffic policemen are more exposed to PAHs (Wang et al. 1978; Schenker 1980; Khesina et al. 1989; Clonfero 1997). There are studies reporting increased chromosomal aberrations and sister chromatid exchanges (SCEs) in individuals exposed to PAHs (Perera et al. 1992; Karahalil et al. 1998; Burgaz et al. 2002).

Petrol with high lead content was in use before the year 1997 in Amritsar. In January 1997, low lead petrol with a lead content of $0.15 \mathrm{~g} / \mathrm{l}$ and in February 2000 unleaded petrol with a lead content of $0.013 \mathrm{~g} / \mathrm{l}$ was introduced in Amritsar (SPAAQMI 2002). Air from petrol in dense traffic areas is a source of environmental lead. As lead has a long half-life and accumulates in human body over a lifetime, including prenatal life, its effects can persist in individuals exposed to it. Unleaded petrol has benzene (CAS 71-43-2) present in it, and both lead and benzene have been shown to have genotoxic effects. There are studies reporting higher blood lead level in traffic policemen exposed to vehicular exhausts than the non-exposed persons (Farsam et al. 1982; Ahmed et al. 1987; Kamal et al. 1991; Bavazzano 1994; Telisman et al. 2000). Studies have shown increased chromosomal aberrations in individuals exposed to lead and benzene (Jablonicka et al. 1987; Huang et al. 1988; Smejkalova 1990; Tompa et al. 1994). As traffic policemen are more exposed to PAHs, lead and benzene, this can also be the cause of increased chromosomal aberrations.

Table 3: Chromosomal aberrations found in traffic policemen according to the duration of exposure

\begin{tabular}{|c|c|c|c|}
\hline Type of aberrations & $\begin{array}{l}\text { Mean } \pm S D \text { in } \\
\text { traffic policemen } \\
\text { working }<10 \text { years }\end{array}$ & $\begin{array}{l}\text { Mean } \pm S D \text { in } \\
\text { traffic policemen } \\
\text { working }>10 \text { years }\end{array}$ & $\begin{array}{l}\text { Student's } \\
t \text {-test } \\
\text { distribution }\end{array}$ \\
\hline & $24.52 \pm 5.72$ & $40.03 \pm 7.84$ & $(\mathrm{p}<0.005)$, sig $^{\mathrm{a}}$ \\
\hline$\%$ fre & $3.44 \pm 2.49$ & $5.65 \pm 2.58$ & $(\mathrm{p}<0.05), \quad$ sig $^{\mathrm{a}}$ \\
\hline & $1.45 \pm 1$ & $3.62 \pm 1.71$ & $(\mathrm{p}<0.005), \mathrm{sig}^{\mathrm{a}}$ \\
\hline$\%$ frequency of metaphases $\mathrm{v}$ & $1.42 \pm 1.27$ & $3.34 \pm 1.34$ & $(\mathrm{p}<0.005), \mathrm{si}$ \\
\hline$\%$ frequency of metaphases with AA & $19.63 \pm 3.72$ & $30.76 \pm 6.09$ & $(\mathrm{p}<0.005), \mathrm{sig}^{\mathrm{a}}$ \\
\hline
\end{tabular}

TAM = Total aberrant metaphases; $\mathrm{NA}=$ Numerical aberrations;

$\mathrm{SA}=$ Structural aberrations; $\quad \mathrm{AA}=$ Acrocentric associations;

$\operatorname{sig}^{\mathrm{a}}=$ Statistically significant difference. 
The results have also shown higher chromosomal aberrations in traffic policemen working more than 10 years as compared to those working less than 10 years (Table 3 ). This shows that chromosomal aberrations are increasing with increasing duration of service. The possible explanation can be that traffic policemen have a consistent and prolonged exposure to the polluted air having petrol and diesel emissions, SPM, PAHs and benzene with increasing duration of service. Lead can also be the cause of increased chromosomal aberrations in traffic policemen, because before the year 2000 leaded petrol was used in Amritsar. So, the traffic policemen working more than 10 years were exposed to the leaded petrol exhausts. Increased chromosomal aberrations have been reported in individuals exposed to lead (Huang et al. 1988; Smejkalova 1990). The result is consistent with the previous study on traffic policemen, in which the authors have found higher values of SCEs after 5 years in traffic policemen who remained in service than in the initial analysis (Chandrasekaran et al. 1996). The result is also consistent with the previous studies on persons exposed to petrol and diesel exhausts, and fumes reporting a positive correlation between increasing exposure duration and higher incidence of chromosomal aberrations (Sobti and Bhardwaj 1993; Chitra et al. 2001).

The percentage frequency of TAM was higher in traffic policemen and controls $\geq 35$ years

Table 4: Percentage frequency of total aberrant metaphases detected in traffic policemen and controls with reference to age and alcohol intake

\begin{tabular}{|c|c|c|c|}
\hline Habits & No. & $T A M(M e a n \pm S D)$ & Student's t-test distribution \\
\hline Traffic policemen $<35$ years in age & 10 & $27.91 \pm 10.49$ & $(\mathrm{p}>0.05)$, non-sigb \\
\hline Traffic policemen $\geq 35$ years in age & 11 & $35.04 \pm 8.28$ & \\
\hline Controls $<35$ years in age & 4 & $13.92 \pm 2.45$ & $(\mathrm{p}>0.05)$, non-sig ${ }^{\mathrm{b}}$ \\
\hline Controls $\geq 35$ years in age & 9 & $12.61 \pm 1.58$ & \\
\hline Traffic policemen taking alcohol & 13 & $34.09 \pm 10.88$ & $(\mathrm{p}>0.05)$, non-sig ${ }^{\mathrm{b}}$ \\
\hline Traffic policemen not taking alcohol & 18 & $27.67 \pm 6.86$ & \\
\hline Controls taking alcohol & 5 & $13.88 \pm 2.47$ & $(\mathrm{p}<0.05), \operatorname{sig}^{\mathrm{a}}$ \\
\hline Controls not taking alcohol & 8 & $12.48 \pm 1.33$ & \\
\hline
\end{tabular}

sig $^{\mathrm{a}}=$ Statistically significant difference.

non-sig ${ }^{\mathrm{b}}=$ Statistically non-significant difference.

Table 5: Summary of previous studies on traffic police workers occupationally exposed to air pollution

\begin{tabular}{|c|c|c|c|c|c|}
\hline $\begin{array}{l}\text { No. of } \\
\text { subjects }\end{array}$ & $\begin{array}{l}\text { No. of } \\
\text { controls }\end{array}$ & Location & $\begin{array}{l}\text { Measured } \\
\text { end point }\end{array}$ & $\begin{array}{c}\text { Results } \\
\text { (+) significantly } \\
\text { higher /(-) non- } \\
\text { significant difference }\end{array}$ & Reference \\
\hline 15 & 23 & $\begin{array}{l}\text { Ankara, } \\
\text { Turkey }\end{array}$ & $\begin{array}{c}\text { Chromosomal } \\
\text { aberrations }\end{array}$ & + & Burgaz et al. (2002) \\
\hline 28 & 15 & $\begin{array}{l}\text { Cairo, } \\
\text { Egypt }\end{array}$ & $\begin{array}{l}\text { Chromosomal } \\
\text { aberrations } \\
\text { SCEs }\end{array}$ & $\begin{array}{l}+ \\
+\end{array}$ & Anwar and Kamal (1988) \\
\hline 23 & 23 & $\begin{array}{c}\text { Madras, } \\
\text { India }\end{array}$ & SCEs & + & Chandrasekaran et al. (1996) \\
\hline 78 & 57 & $\begin{array}{l}\text { Lanzhou, } \\
\text { China }\end{array}$ & $\begin{array}{l}\text { Micronuclei } \\
\text { SCEs }\end{array}$ & $\begin{array}{l}+ \\
+\end{array}$ & Zhao et al. (1998) \\
\hline 82 & 34 & $\begin{array}{l}\text { Genoa, } \\
\text { Italy }\end{array}$ & Micronuclei & - & Bolognesi et al. (1997a) \\
\hline 54 & 35 & $\begin{array}{l}\text { Genoa, } \\
\text { Italy }\end{array}$ & SCEs & - & Bolognesi et al. (1997b) \\
\hline 94 & 52 & $\begin{array}{l}\text { Genoa, } \\
\text { Italy }\end{array}$ & $\begin{array}{l}{ }^{32} \mathrm{P}-\text { postlabelling } \\
\text { DNA adducts } \\
\text { Micronuclei }\end{array}$ & + & Merlo et al. (1997) \\
\hline 15 & 20 & $\begin{array}{l}\text { Ankara, } \\
\text { Turkey }\end{array}$ & Micronuclei & + & Karahalil et al. (1999) \\
\hline 133 & 57 & $\begin{array}{l}\text { Rome, } \\
\text { Italy }\end{array}$ & $\begin{array}{l}\text { SCEs } \\
\text { Alkaline comet assay }\end{array}$ & $\begin{array}{l}+ \\
-\end{array}$ & Carere et al. (2002) \\
\hline 44 & 45 & $\begin{array}{l}\text { Bangkok, } \\
\text { Thailand }\end{array}$ & $\begin{array}{l}{ }^{32} \mathrm{P}-\text { postlabelling } \\
\text { DNA adducts } \\
\text { Serum PAH-albumin } \\
\text { adduct level }\end{array}$ & $\begin{array}{l}+ \\
+\end{array}$ & Ruchirawat et al. (2002) \\
\hline
\end{tabular}


in age as compared to $<35$ years in age, but the differences were non-significant. Thus, the clear effect of age was not seen.

In controls taking alcohol, the mean percentage of TAM was significantly higher, but in traffic policemen taking alcohol the aberrations were non-significantly higher than the subjects not taking alcohol (Table 4). Thus, alcohol intake could be having a synergistic effect on chromosomal damage being caused by air pollution. but as intake of alcohol was infrequent and in less quantity, the independent effect of alcohol in traffic policemen could not be ascertained. Ethanol reportedly also induces increase in the biologically active or mobile fraction of lead in body (Telisman et al. 2000) and can exacerbate the genotoxic effect of lead. Thus, the increasing age and alcohol intake were also contributing to the increase in chromosomal aberrations caused by increased pollution.

The results of this study are consistent with the previous studies on traffic police workers (Table 5), in which higher frequency of chromosomal aberrations and SCEs was detected in traffic policemen as compared to controls (Anwar and Kamal 1988; Chandrasekaran et al. 1996; Zhao et al. 1998; Burgaz et al. 2002).

The results of this study have shown increased chromosomal aberrations in traffic policemen as compared to controls and also an increase in acrocentric associations. This indicates occupational exposure to polluted air having increased automobile exhausts can have genotoxic effects and these effects increase with increasing duration of exposure. Thus, chromosomal aberrations, including acrocentric associations, can be used for biomonitoring the genotoxic effects of occupational exposure to urban air pollutants.

\section{REFERENCES}

Ahmed NS, el-Gendy KS, el-Refaie AK, Marzouk SA, Bakry NS, el-Sebae AH, Soliman SA 1987. Assessment of lead toxicity in traffic controllers of Alexandria, Egypt, road intersections. Arch Environ Health, 42: 92-95.

Anwar WA, Kamal AAM 1988. Cytogenetic effects in a group of traffic policemen in Cairo. Mutat Res, 208: $225-231$

Bavazzano P, Cotti G 1994. Biological monitoring of lead in the study of urban pollution due to automobile traffic. Epidemiol Prev, 18: 27-34.

Bolognesi C, Gallerani E, Bonatti S, De Ferrari M, Fontana V, Valerio F, Merlo F, Abbondandolo A 1997a. Sister chromatid exchange induction in peripheral blood lymphocytes of traffic police workers. Mutat Res, 394: 37-44.

Bolognesi C, Merlo F, Rabboni R, Valerio F, Abbondandolo A 1997b. Cytogenetic biomonitoring in traffic police workers: micronucleus test in peripheral blood lymphocytes. Environ Mol Mutagen, 30: 396-402.

Burgaz S, Dermircigil GC, Karahalil B, Karakaya AE 2002. Chromosomal damage in peripheral blood lymphocytes of traffic policemen and taxi drivers exposed to urban air pollution. Chemosphere, 47: 57-64.

Carere A, Andreoli C, Galati R, Leopardi P, Marcon F, Rosati MV, Rossi S, Tomei F, Verdina A, Zijno A, Crebelli R 2002. Biomonitoring of exposure to urban air pollutants: analysis of sister chromatid exchanges and DNA lesions in peripheral lymphocytes of traffic policemen. Mutat Res, 518: 215-224.

Carere A, Antoccia A, Crebelli R, Degrassi F, Fiore M, Iavarone I, Isacchi G, Lagorio S, Leopardi P, Marcon F, Palitti F, Tanzarella C, Zijno A 1995. Genetic effects of petroleum fuels: cytogenetic monitoring of gasoline station attendants. Mutat Res, 332: 1726.

Chandrasekaran R, Samy PLP, Murthy PBK 1996. Increased sister chromatid exchange (SCE) frequencies in lymphocytes from traffic policemen exposed to automobile exhaust pollution. Hum Exp Toxicol, 15: 301-304.

Chitra CK, Vishwanathan H, Deepa E, Rani MVU 2001. Cytogenetic monitoring of men occupationally exposed to airborne pollutants. Environ Pollut, 112: 391-393.

Clonfero E 1997. Genotoxicity of urban air particulate matter. Med Lav, 88: 13-23.

Clonfero E, Saia B 1991. Mutagens and carcinogens in city air. G Ital Med Lav, 13: 9-15.

DTO 2004. Registered Vehicles of Amritsar (personal communication). District Transport Office, Amritsar, India.

Farsam H, Salari GH, Nadim A 1982. Absorption of lead in Tehran traffic policemen. Am Ind Hyg Assoc J, 43: $373-376$

Hogstedt B, Gullberg B, Mark-Vendel E, Mitelman F, Skerfving S 1981. Micronuclei and chromosome aberrations in bone marrow cells and lymphocytes of humans exposed mainly to petroleum vapors. Hereditas, 94: 179-187.

Huang XP, Feng ZY, Zhai WL, Xu JH 1988. Chromosomal aberrations and sister chromatid exchanges in workers exposed to lead. Biomed Environ Sci, 1: 382-387.

Jablonicka A, Vargova M, Karelova J 1987. Cytogenetic analysis of peripheral blood lymphocytes in workers exposed to benzene. J Hyg Epidemiol Microbiol Immunol, 31: 127-132.

Kamal AAM, Eldamaty SE, Faris R 1991. Blood lead level of Cairo traffic policemen. Sci Total Environ, 105: $165-170$.

Karahalil B, Burgaz S, Fisek G, Karakaya AE 1998. Biological monitoring of young workers exposed to polycyclic aromatic hydrocarbons in engine repair workshops. Mutat Res, 412: 261-269.

Karahalil B, Karakaya AE, Burgaz S 1999. The 
micronucleus assay in exfoliated buccal cells: application to occupational exposure to polycyclic aromatic hydrocarbons. Mutat Res, 442: 29-35.

Khalil AM 1995. Chromosome aberrations in blood lymphocytes from petroleum refinery workers. Arch Environ Contam Toxicol, 28: 236-239.

Khesina A, Makhover MS, Khitrovo IA 1989. Distribution, formation, carcinogenic and mutagenic activities of nitro derivatives of polycyclic aromatic hydrocarbons. Eksp Onkol, 11: 3-8.

Knudsen LE, Norppa H, Gamborg MO, Nielsen PS, Okkels H, Soll-Johanning H, Raffn E, Jarventaus H, Autrup H 1999. Chromosomal aberrations in humans induced by urban air pollution: influence of DNA repair and polymorphisms of glutathione-Stransferase M1 and N-acetyltransferase 2. Cancer Epidemiol Biomark Prev, 8: 303-310.

Merlo F, Bolognesi C, Peluso M, Valerio F, Abbondandolo A, Puntoni R 1997. Airborne levels of polycyclic aromatic hydrocarbons: ${ }^{32} \mathrm{P}$-postlabelling DNA adducts and micronuclei in white blood from traffic police workers and urban residents. J Environ Pathol Toxicol Oncol, 16: 157-162.

Moorhead PS, Nowell PC, Mellman WJ, Battips DM, Hungerford DA 1960. Chromosome preparations of leukocytes cultured from human peripheral blood. Exp Cell Res, 20: 613-616.

NAAQSI (National Ambient Air Quality Standards for India) 2003. www.geocities. com/envis_ism/ standard2.html.

Perera FP, Hemminkit K, Gryzbowska E, Motykiewicz G, Michalska J, Santella RM, Young T-L, Dickey C, Brandt-Rauf P, De Vivo I, Blaner W, Tsai W-Y, Chorazy M 1992. Molecular and genetic damage in humans from environmental pollution in Poland. Nature, 360: 256-258.

PPCB 2004. Pollution Profile of Amritsar (personal communication). Punjab Pollution Control Board, Patiala, India.

Ruchirawat M, Mahidol C, Tangjarukij C, Pui-ock S, Jensen O, Kampeerawipakorn O, Tuntaviroon J, Aramphongphan A, Autrup H 2002. Exposure to genotoxins present in ambient air in Bangkok, Thailand - particle associated polycyclic aromatic hydrocarbons and biomarkers. Sci Total Environ, 287: $121-132$.

Schenker MB 1980. Diesel exhaust - an occupational carcinogen? J Occup Med, 22: 41-46.
STP 2004. City Plan of Amritsar (personal communication). Senior Town Planner, Amritsar, India.

Smejkalova J 1990. The chromosomal aberrations in children permanently living in the lead polluted area. Sb Ved Pr Lek Far Karlovy Univ Hradci Kralove, 33: 539-564.

Sobti RC, Bhardwaj DK 1993. Cytogenetic damage and exposure.II. Exposure to petroleum exhaust. Mutagenesis, 8: 101-103.

SPAAQMI (Strategy and Policy Adopted in Air Quality Management in India) (online)2002. www.cse. polyu.edu.hk/ activi/BAQ2002/BAQ2002_files/ Proceedings/PosterSession/41f.

State Information(online) 2003. http://www.punjabgov. net/info_stat.asp\#1.

Telisman S, Critkovic P, Jurasovic J, Piczut A, Garella M, Rocie B 2000. Semen quality and reproductive endocrine function in relation to biomarkers of lead, cadmium, zinc, and copper in men. Environ Health Perspect, 108: 45-53.

Tompa A, Major J, Jakab MG 1994. Monitoring of benzene-exposed workers for genotoxic effects of benzene: improved working condition related decrease in the frequencies of chromosomal aberrations in peripheral blood lymphocytes. Mutat Res, 304: 159-165.

Vehicular Pollution (online)2003. www.punjabenvironment.com/air_veh.html.

Wang YY, Rappaport SM, Sawyer RF, Talcott RE, Wei ET 1978. Direct-acting mutagens in automobile exhaust. Cancer Lett, 5: 39-47.

WHO (World Health Organization)(online)2003a. Air Quality Guidelines - Classical Pollutants Particulate Matter. http://www.euro.who.int/ document/aiq/7_3particulate-matter.

WHO (World Health Organization) (online)2003b. Air Quality Guidelines - General Summary of the Guidelines. http://www.euro.who.int/document/aiq/ 3 summary.

Zhao X, Nu J, Wang Y, Yan C, Wang X, Wang J 1998. Genotoxicity and chronic health effects of automobile exhaust: a study on the traffic policemen in the city of Lanzhou. Mutat Res, 415: 185-190.

Zhao X, Wan Z, Chen G, Zhu H, Jiang S, Yao J 2002. Genotoxic activity of extractable organic matter from urban airborne particles in Shanghai, China. Mutat Res, 514: 177-192. 